Journal of the Society of Rheology, Japan Vol.30, No.4, $173 \sim 178$ (2002)

(Nihon Reoroji Gakkaishi)

\title{
Article
}

C2002 The Society of Rheology, Japan

\section{Variation in Mechanical Properties of Rat Vertebrae with Age and Their Relation to Bone Density}

\author{
Yoshio SHIRASAKI*, Ikuo AIDA**, Tetsuya TATEISHI ${ }^{* * *}$, and Kazuhiko HAYASHI*

\begin{abstract}
*National Institute of Advanced Industrial Science and Technology, Namiki 1-2 Tsukuba-shi, Ibaraki 305-0044, Japan
**Department of Orthopedic Surgery, University of Tsukuba, Tennodai 1-1, Tsukuba-shi, Ibaraki 305-0044, Japan
\end{abstract} \\ ***Faculty of Mechanical Engineering, University of Tokyo, Hongo 7-3-1, Bunkyo-ku, Tokyo 113-8656, Japan

\begin{abstract}
Aging effect on the mechanical properties and bone density of the rat cervical and lumber spine were evaluated from
\end{abstract} \\ young to old specimens. The dynamic viscoelastic properties were measured by a viscoelastic spectrometer. The static \\ test was performed with an Instron-type universal testing machine. We examined dynamic stiffness, tan $\delta$, fracture load, \\ ultimate strength, and deformation energy of the cervical and lumber spine over several period of the time. Bone mineral \\ content was measured by dual X-ray absorptiometry at the femoral diaphysis, femoral distal and lumber 3(L3). The \\ dynamic stiffness and tan $\delta$ without the soft tissue around lumber spine indicated a second order polynomial function of \\ age, but cervical spine showed no clear trend with age. Fracture load of the cervical and lumber spine indicated a second \\ order polynomial function of age. We also found linear relations between the mechanical properties and density of bone.
}

\section{加齢によるラット 骨の力学特性と骨密度の変化}

\author{
白崎 芳夫 ${ }^{* 1}$ ，会田 育男 ${ }^{* 2}$ ，立石 哲也 ${ }^{* 3}$ ，林 和彦*1
}

(原稿受理：2002年2月 1 日)

1. 緒言

ヒトの運動機能は大部分，筋・骨格系の働きに依存してい る. 骨格系の中でも身体の中軸をなす, 脊柱の加齢による力 学特性と骨密度変化を明らかにすることは, 生物学的, 臨床 医学的にも重要な意味をもっている.

本報告では, 脊柱の力学特性と骨密度の年齢依存性を明ら かにする目的で, 実験動物（ラット）の頸椎と腰椎を用いて 力学特性の変化を測定し, 同一試料の大腿骨および腰椎の骨 密度を調べた結果について述べる。

\section{2. 実験}

本実験に用いたラット (Wistar-Kyoto Rat) は,生後3週より 飼育し, 5 週から 98 週龄まで測定した . 各グループの試料数 はn $=6$ 8個体である .

脊柱は新鮮屍体より採取した後, 椎体周囲の筋肉および靬 帯組織を可及的に切除し, 頸椎は第1頸椎から第3頸 $\left(\mathrm{C}_{1} \sim \mathrm{C}_{3}\right)$ と第1胸椎から第3胸椎 $\left(\mathrm{T}_{1} \sim \mathrm{T}_{3}\right)$ をボーンセメントで固定し た .腰椎については上方は第10胸椎から第 12 胸椎 $\left(\mathrm{T}_{10} \sim \mathrm{T}_{12}\right)$,

*1 産業技術総合研究所

T 305-8564 茨城県つくば市並木 1-2

*2 筑波大学 - 整形外科

干 305-8573 茨城県つくば市天王台 1-1

*3 東京大学大学院工学系研究科

干 113-8656 東京都文京区本郷 7-3-1
下方は仙椎を同じくボーンセメントで固定した .

力学特性は上記試料の粘弾性特性を測定した .さらに , 同 一試料の椎弓・椎間関節 (後方要素) を切除後にも同樣な測 定をおこない, 弚の後, 静的引張試験を実施した。

粘弾性特性は本研究室で開発した, 動的粘弾性測定装置 (オリエンテック社製) を用いて測定した . 脊柱の後方要素 切除前では周波数 $35 \mathrm{~Hz}$, 静的引張荷重 $5.0 \mathrm{~N}$, 振幅 $2.0 \mathrm{~N}$ の動荷 重を負荷した . 後方要素切除後は, 周波数 $35 \mathrm{~Hz}$, 静的引張荷 重 $2.0 \mathrm{~N}$, 振幅 $1.0 \mathrm{~N}$ の動荷重を重畳して, 荷重・変位応答を測 定した．すなわち，荷重

$$
F=F_{0}+F_{1} \sin \omega t
$$

\section{に相当する変位}

$$
D=D_{0}+D_{1} \sin (\omega t-\delta)
$$

より，動的スチフネス (Dynamic stiffness) $F_{1} / D_{1}(\mathrm{~N} / \mathrm{mm})$ と 位相差 ( $\tan \delta)$ を測定した。

粘弾性特性を測定した後，引張試験を実施した。 引張試験 はインストロンタイプの万能試験機を用い, クロスヘッドス

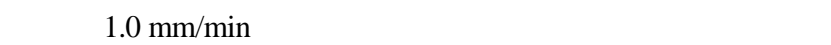
(Fractute Load)，破断強度 (Fractute Stress, 破断荷重を破断面 積で割った值)，破断までの荷重・変位曲線の面積から変形 エネルギ (Deformation Energy) を求めた . 実験中は試料の乾 
燥を防ぐため生理食塩水を点滴した .

骨密度はDEXA (Dual Energy X-ray Absorptiometry , DCS-600 アロカ社製) 法によって計測した。

\section{3. 結果と考察}

\section{1 動的試験}

Fig.1は頸椎のスチフネスの週齢による変化を示す . (以下， データは平均値と標準偏差を示す) スチフネスの值は24週齡

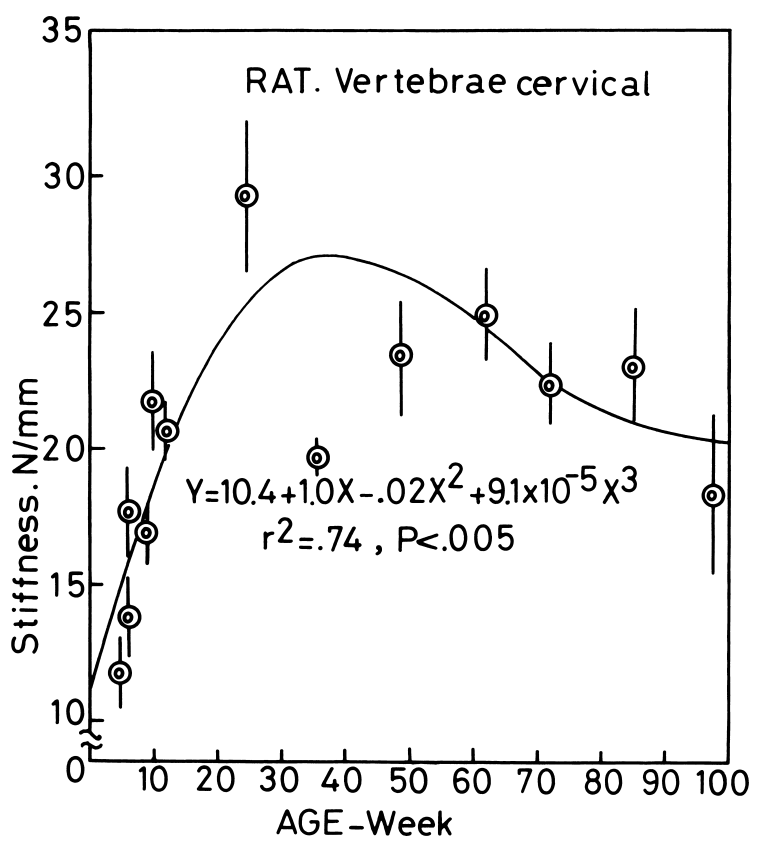

Fig.1 Variation of cervical stiffness with time (with soft tissue around).

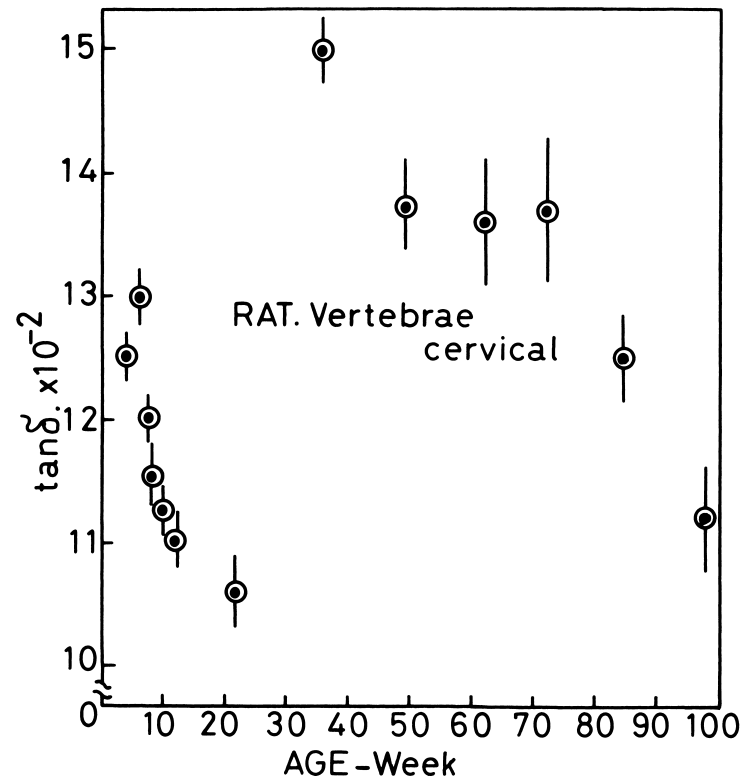

Fig.2 Variation of cervical $\tan \delta$ with time (with soft tissue around).
までは増加し，光の後，減少し48週から84週齢までは大きな 変化はなく98週齢で咸少している.スチフネスと週齢の関係 を回帰分析により求めると図中のような3次式で表される .

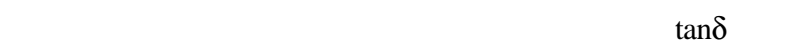

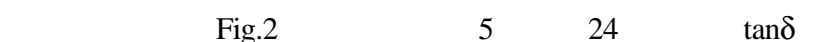
值は減少し，36週で最大になり，弚れ以後72週齢までは大差 なく，84週，98週齢で咸少している。

スチフネスと $\tan \delta の$ 变化を成長期 (ラットの場合, 9 週齢ま たは 10 週龄以降を成長ラット，成熟ラットと呼び，光れ以前 を成長期と呼んでいる) に注目してみると Fig.3のようにな る . スチフネスの值は 5 週から 24 週齢まで週齢の増加にした

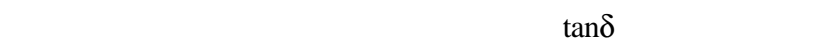

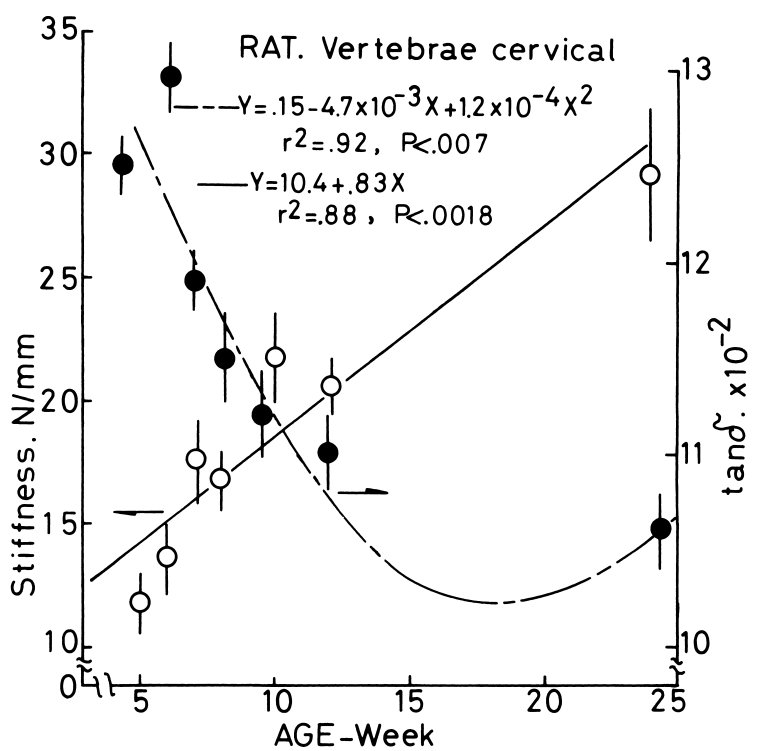

Fig.3 Variation of cervical stiffness and $\tan \delta$ with time from 5 week to 24 week.

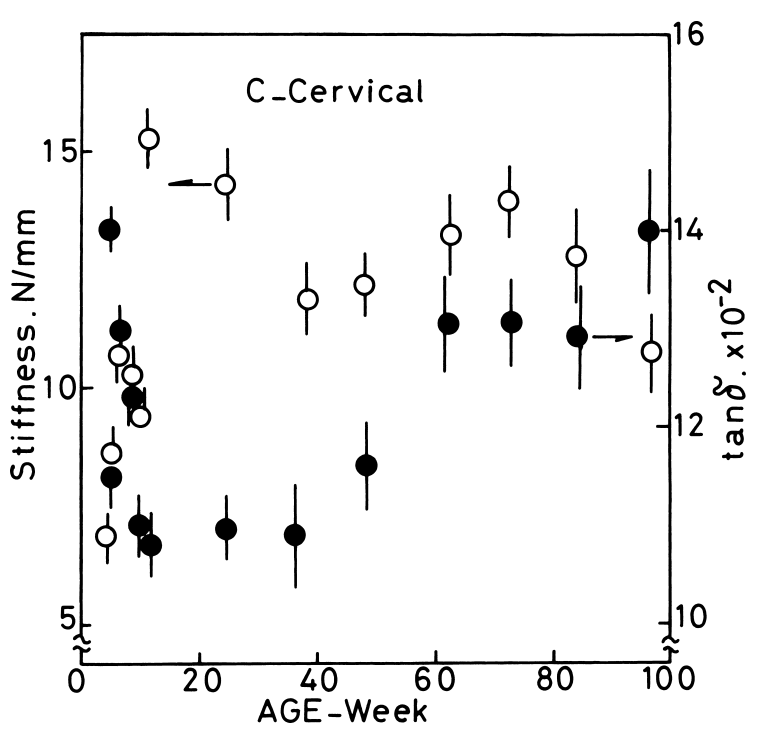

Fig.4 Variation of cervical stiffness and $\tan \delta$ with time (without soft tissue around) 
加に伴い減少している . 成長期ラットの頸椎は週齢の増加に

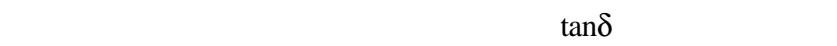
いる.この結果から，成長期ラットの頸椎は時間経過（週齢 の増加) とともに, 頸椎全体力弾性 (脆性) 的な材料に変化し

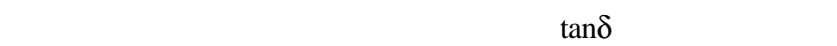
析によって回帰式を求めると, スチフネスは正の1次式 , $\tan \delta$ は負の2次式で各々図中のように表され有意差も確認した .

Fig.4は椎弓・椎間関節 (後方要素) 切除後のスチフネス， $\tan \delta$ と週齢の関係を示す . スチフネスの值は切除前に比較し て全体的に低くなっている. $\tan \delta の$ 值はスチフネスのような 一定の傾向は見られない . 切除前のスチフネスの最大值は $29.2 \mathrm{~N} / \mathrm{mm}$ であり，切除後の最大值は 12 週齡の $15.0 \mathrm{~N} / \mathrm{mm}$ で 48.6 \%減少している. 5 週齢では切除前では $11.7 \mathrm{~N} / \mathrm{mm}$ であり，切 除後では $6.8 \mathrm{~N} / \mathrm{mm}$ になり $42.0 \%$ \%減少になっている .このよ うに，切除後では切除前の值の $40 〜 50 \%$ に減少している.し

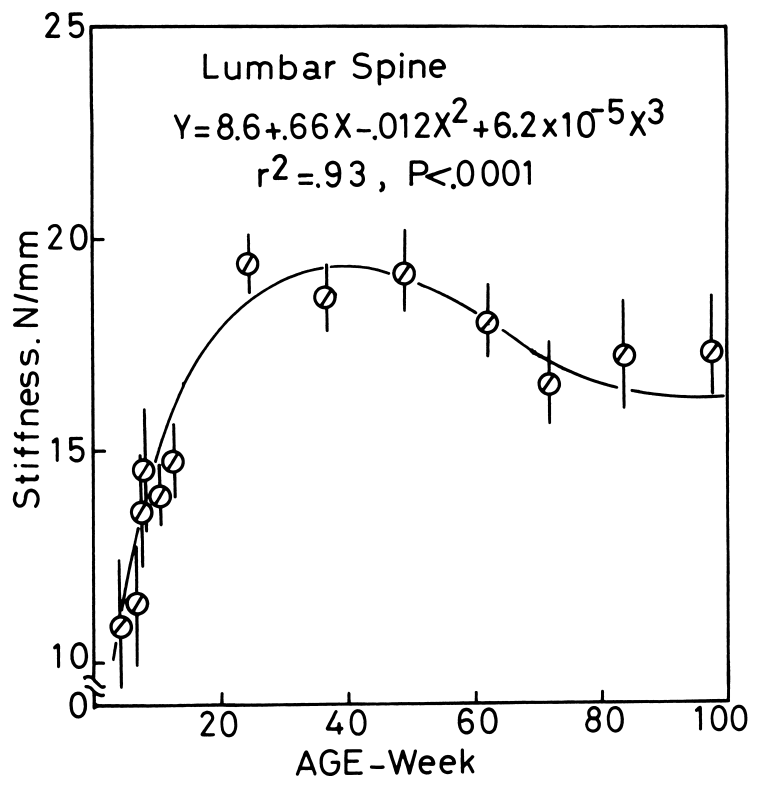

Fig.5 Variation of lumber stiffness with time (with soft tissue around).

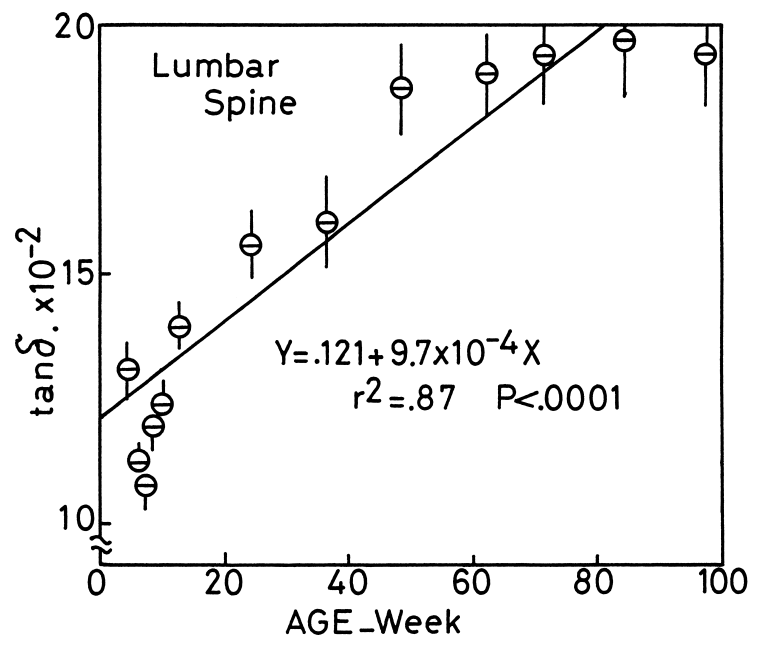

Fig.6 Variation of lumber $\tan \delta$ with time (with soft tissue around).
たがって，この隇少分は後方要素と产の周囲の軟部組織が 担っていたことか明らかになった .

Fig.5に腰椎のスチフネスの週齢依存性を示す . 5 週から 24 週齢まではスチフネスは週齢の増加とともに大きくなって いる. 弚れ以降98週齢までは多少増減が見られるが大きな変 化は表れない，頸椎と比較してみると，24週齢までは週齢の 増加とともにスチフネスの值が大きくなり同樣な傾向を示 している.36週齢以降では腰椎のスチフネスの増減は頸椎に 比較して安定している .この関係を回帰分析により回帰式を 求めると图中のような3次式で表され有意差も存在した .

これに対応する振動荷重と変位の位相差 $\tan \delta$ 週龄依存性

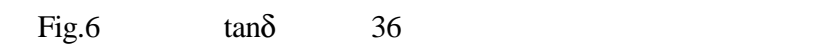

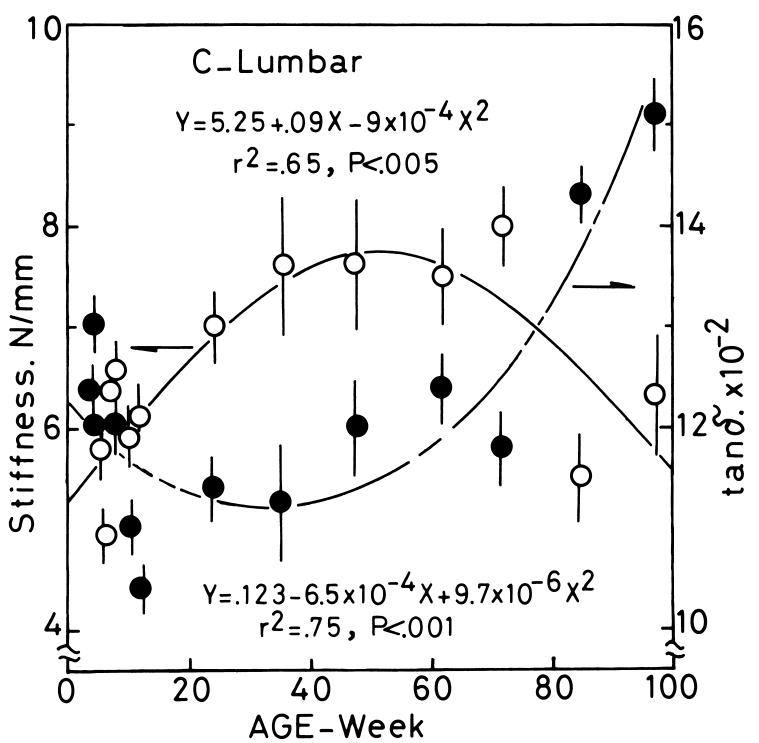

Fig.7 Variation of stiffness and tan $\delta$ with time (without soft tissue around).

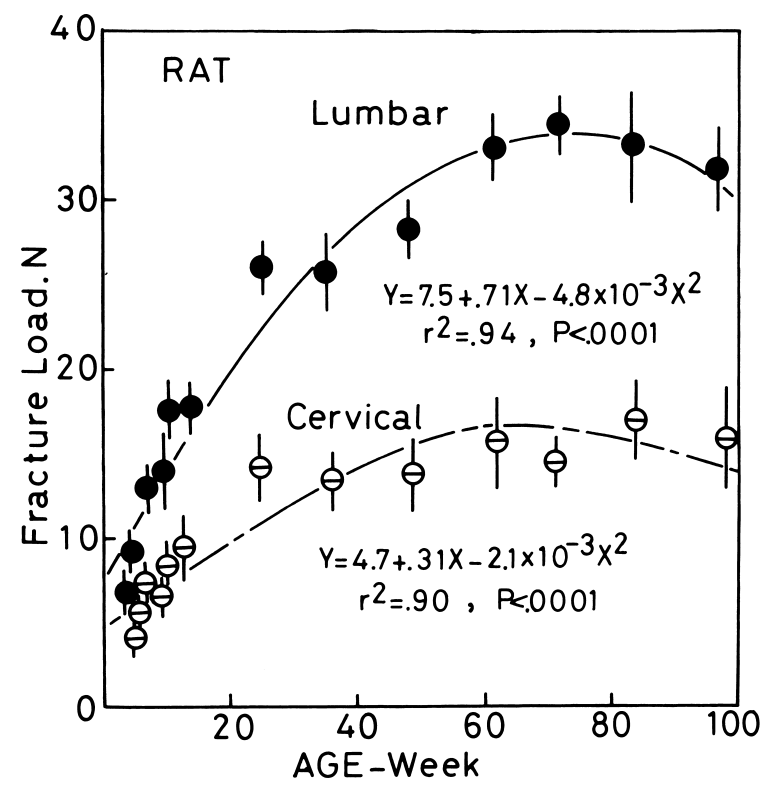

Fig.8 Variation of fracture load with time (cervical and lumber spine). 
きくなっている .48週以降では $\tan \delta の$ 值はほぼ一定の值を示 している. 頸椎と比較してみると, 頸椎では成長期（5週〜 24週齢) ではスチフネスカ増加し, $\tan \delta の$ 值は減少して弾性 (脆性) 的な材料に変化しているのに対し, 腰椎ではスチフ ネス, $\tan \delta$ とも増加して載荷能力と粘弾性効果を兼備えた 材料に変化して頸椎とは大きく異なった材料になっている ことを明らかにした . $\tan \delta$ と週齢の関係を回帰式で表すと图 中のような1次式になり有意差も認められた .

この腰椎の後方要素を切除した後のスチフネスと $\tan \delta の$ 週 齢依存性をFig.7に示す . スチフネスの值は36週まで増加傾向 にあり36週から62週まではほぼ一定で72週では若干増加し， 产れ以降減少している. スチフネスの值は後方要素切除前で は24週齢で $19.4 \mathrm{~N} / \mathrm{mm}$, 弚れ以降 62 週齢までは $18.0 \mathrm{~N} / \mathrm{mm}$ の間 の值になっている . 切除後では24週齢の值は7.0 $\mathrm{N} / \mathrm{mm}$ て切除 前の $64 \%$ 減少になっている. この減少率は頸椎の切除前と切 除後の減少率 $40 \sim 50 \%$ に比較して $10 \%$ 以上大きく, 腰椎の後 方要素は頸椎の後方要素より荷重支持の役割が大きいこと を示唆している。

粘弾性効果の指標である $\tan \delta の$ 值は全体的にスチフネスと 同樣に後方要素切除前の値より低下している . 後方要素を切

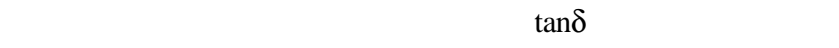
ることは載荷能力とともに粘弾性効果も減少し材料的には 脆弱な材料に変化していることが判明した . スチフネスと $\tan \delta$ 週齢による回帰式を求めると, 图中のようにスチフネ スは負の2次関数, $\tan \delta は$ 正の 2 次関数で表され各々有意差も 見出された .

\section{2 静的試験}

Fig.8は腰椎と頸椎の破断荷重の週龄依存性を示す. 破断荷 重は腰椎か頸椎より大きく, 頸椎の破断荷重は24週齢以降で は13.3〜17.2 N, 腰椎では25.8〜34.0Nになって頸椎の平均值 と標準偏差は $14.8 \pm 1.4 \mathrm{~N}$, 腰椎の弚れは $30.3 \pm 3.6 \mathrm{~N}$ て腰椎の

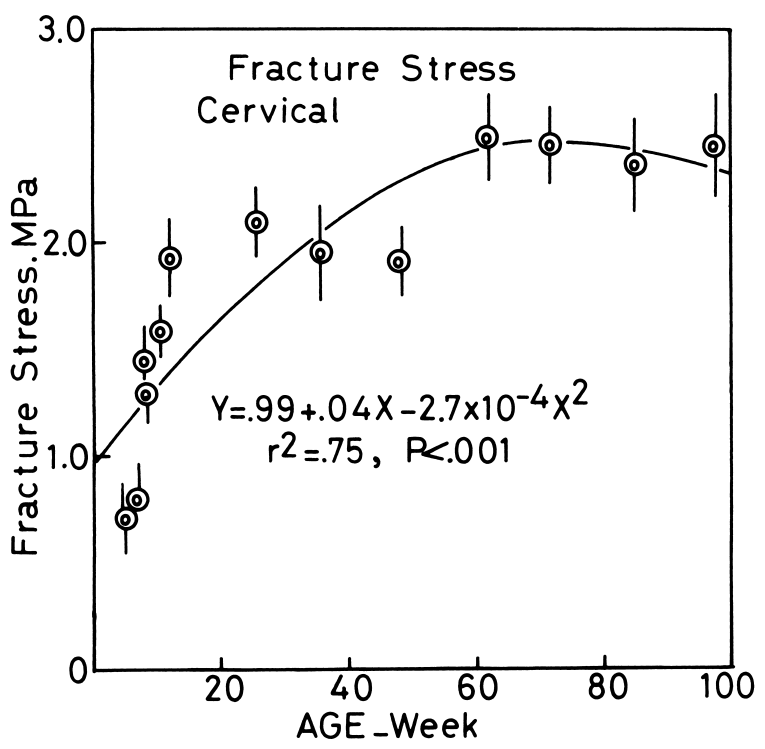

Fig.9 Variation of cervical fracture stress with time.
破断荷重は平均値で2倍になっている.頸椎および腰椎の破 断荷重の週龄依存性の回帰式を求めると，双方とも図中のよ うに負の2次関数で表され有意差も確認された .

頸椎の破断強度の週龄依存性をFig.9に示す.破断強度は 12 週龄までは直線的に増加し，24週から48週齢までは減少傾向 にあり，62週からは大差はない . 週齢による回帰式を求める と図中のような負の2次式になり有意差も認められた .

Fig.10 (a)(b) に頸椎および腰椎の変形エネルギの週龄依存 性を示す . (a)は頸椎 , (b)は腰椎の変形エネルギを表してい る。頸椎のエネルギは図から明らかなように正の 2 次関数で 表されるのに対し, 腰椎のエネルギは直線で近似でき傾向 が相違していることが判明した。

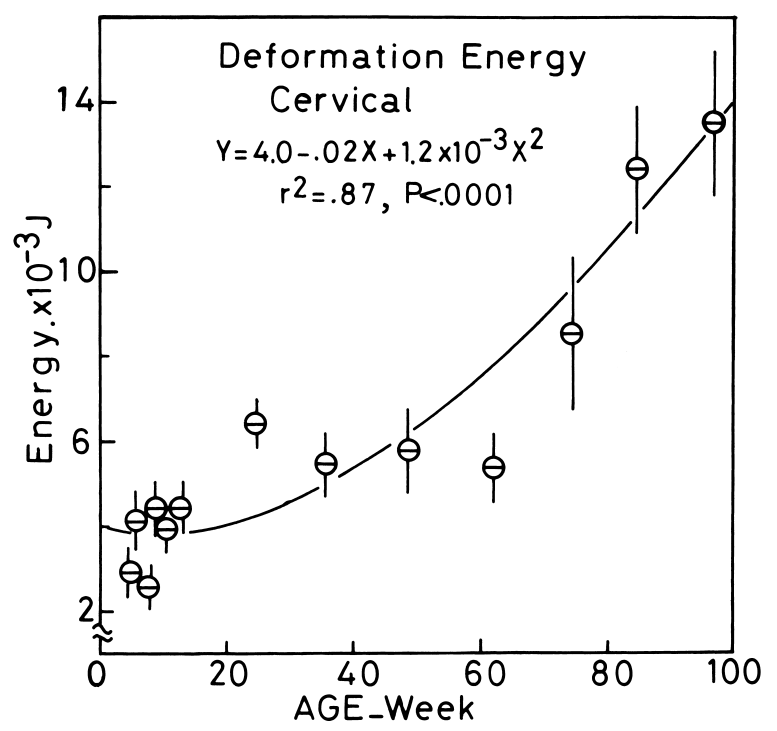

a) Cervical

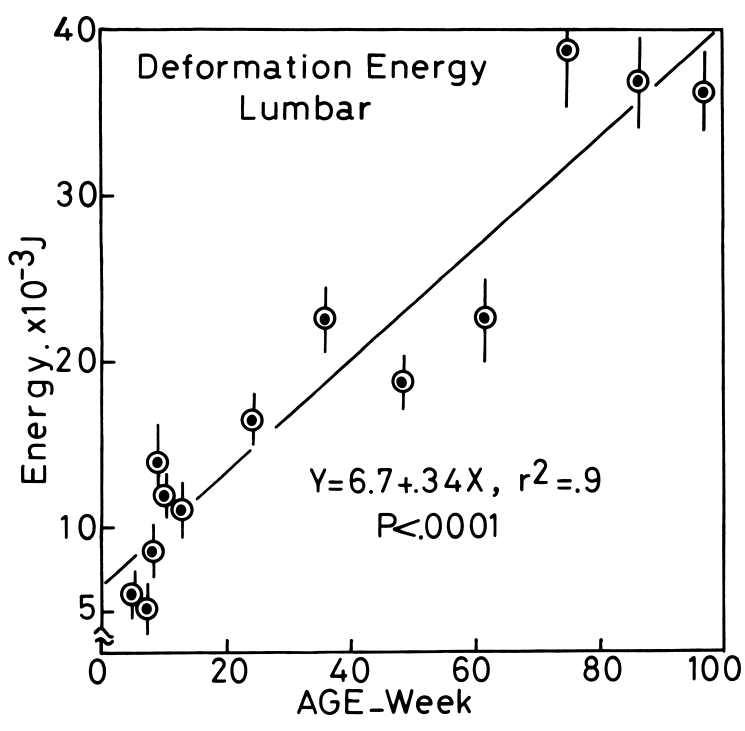

b) Lumber

Fig.10 Variation of deformation energy with time. 


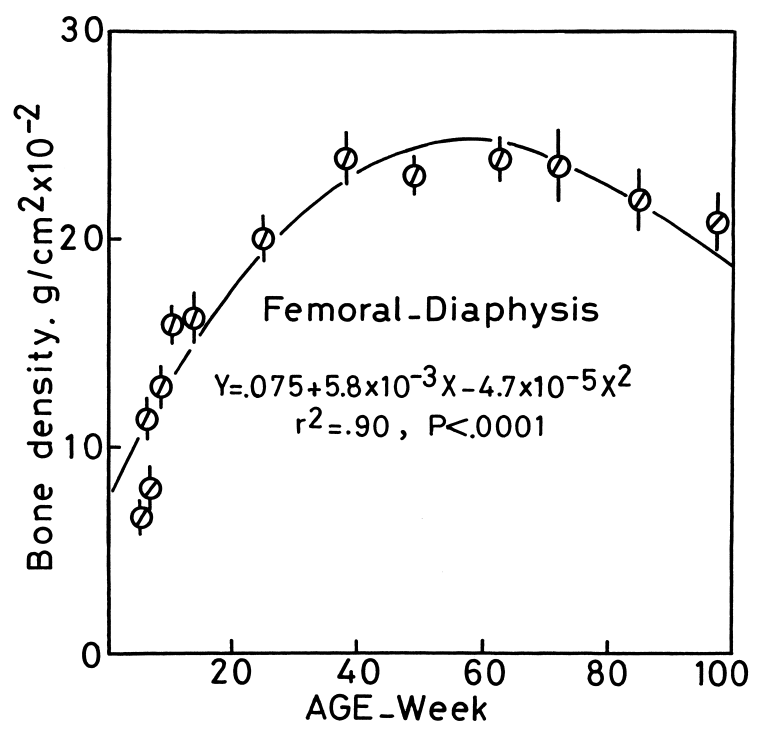

a) Femoral-diaphysis

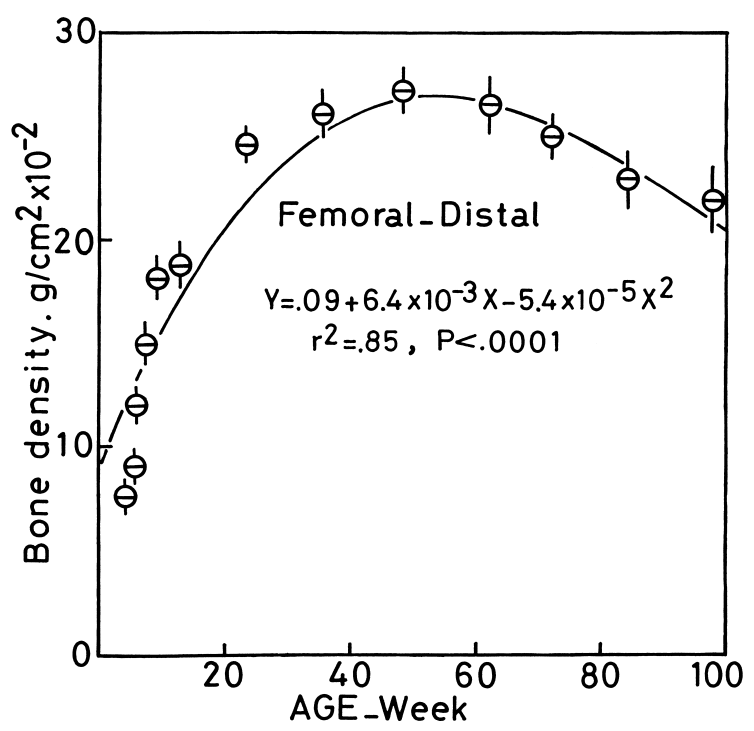

b) Femoral-distal

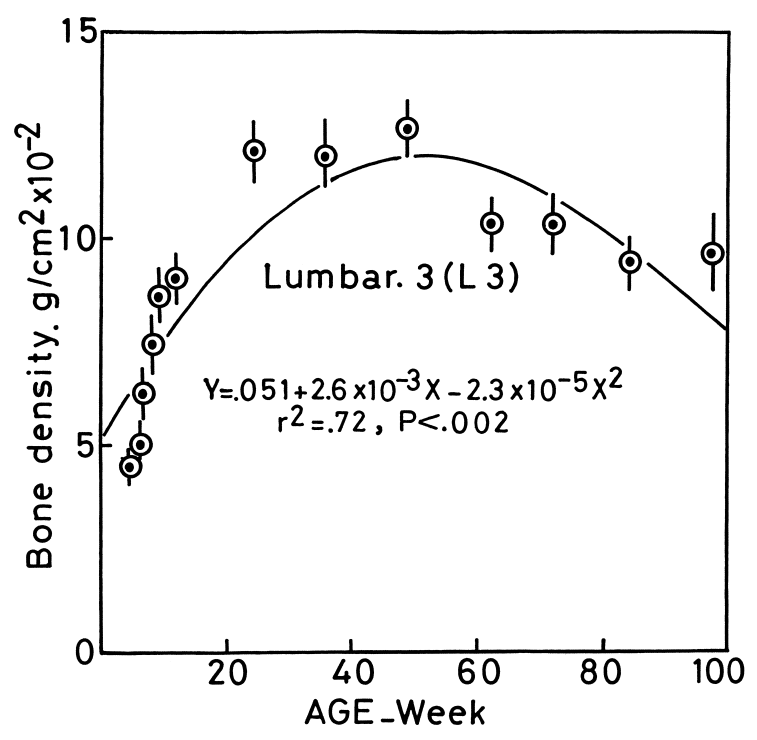

c) Third Lumber (L3)

\section{3 骨密度}

骨密度は大泼骨々幹部（Femoral-Diaphysis），膝関節を構成 している大腿骨遠位部 (Femoral-Distal) と第3腰椎 (L3) に ついて測定した.Fig.11の(a)は大腿骨々幹部、(b)は大腿骨遠 位部、(c)は第 3 腰椎の骨密度の週齡依存性を示す。骨密度の 変化はすべて 5 週齢から週齢の増加とともに值が大きくな り、部位によって24週齢と 30 週齗後半で最大值になり、光れ 以後、週齢の増加とともに減少する傾向にあり各々の回帰式 を求めると図中のような式で表され有意差も見出された。

第3腰椎 (L3) の海綿骨の骨梁構造を明らかにするため骨 梁の平均厚さと単位骨量を測定した。

Fig.12 は骨梁の平均厚さの週齢依存性を示す . 骨梁の平均 厚さの最大值は 12 週と 24 週齢で $80.0 \mu \mathrm{m}$, 最低值は 84 週齢の

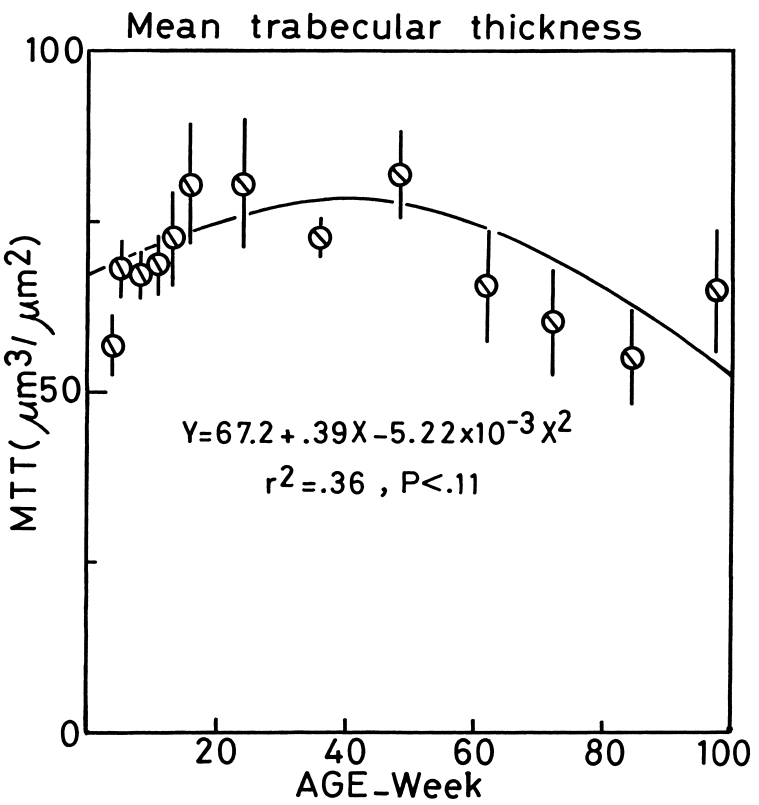

Fig.12 Variation of mean trabecular thickness with time.

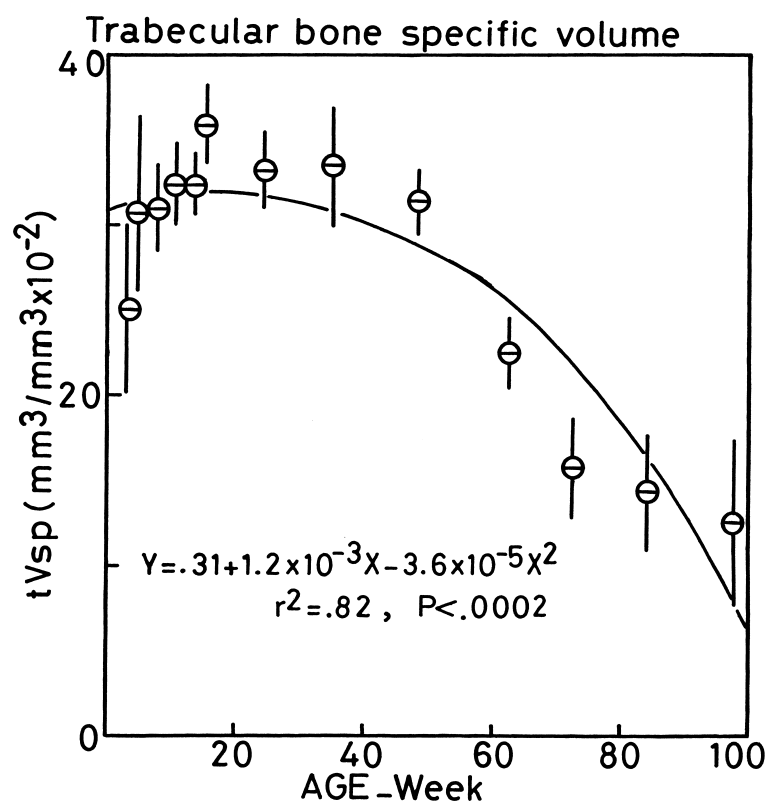

Fig.13 Variation of trabecular bone specific volume with time. 
$55.0 \mu \mathrm{m}$ であり, 最大值からの減少率は $31.3 \%$ になっている . この関係を求めると図中のような式で表されるが有意差は 見られなかった .

Fig.13は単位骨量 (単位面積あたりの骨量の占める割合) の 週齢依存性を示す . 骨量の最大値は 12 週齢の 37 であり, 最低 值は 12.5 , 最大値からの減少率は $66.2 \%$ にっている .この 関係の回帰式は図中のようになり有意差も認められた .

この結果から, 骨量の減少率は平均厚さの減少率の 2 倍以 上になって, 加齢による海綿骨の構造変化は骨梁の厚さより 骨量の減少か顕著になっていることが明らかになった．

\section{4 骨密度と力学特性}

Fig.14は腰椎後方要素切除前のスチフネスと第3腰椎の骨 密度の関係を示す . 骨密度の増加とともにスチフネスの值も

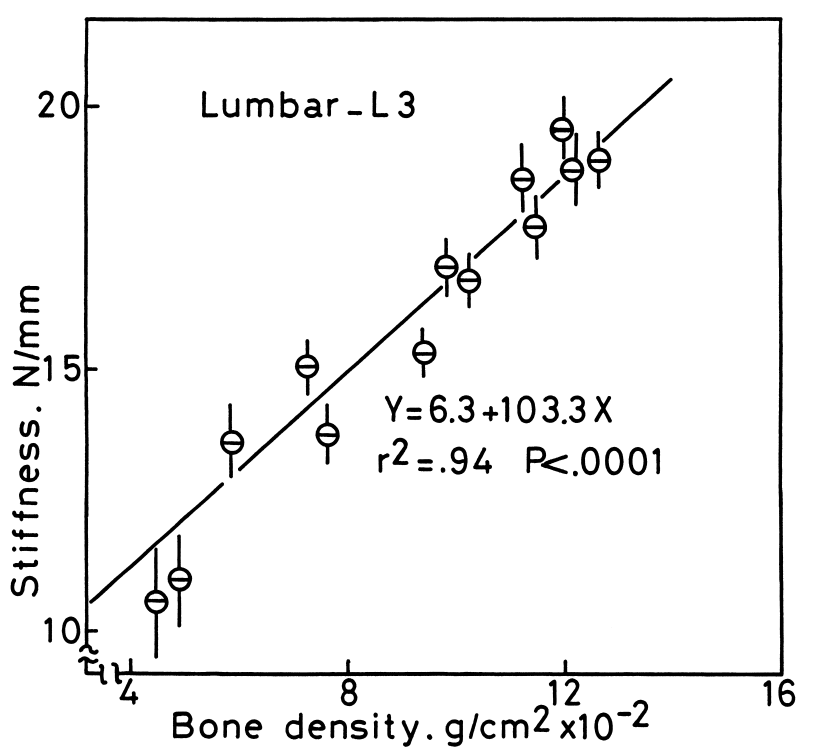

Fig.14 Relation between stiffness and density of bone (L3).

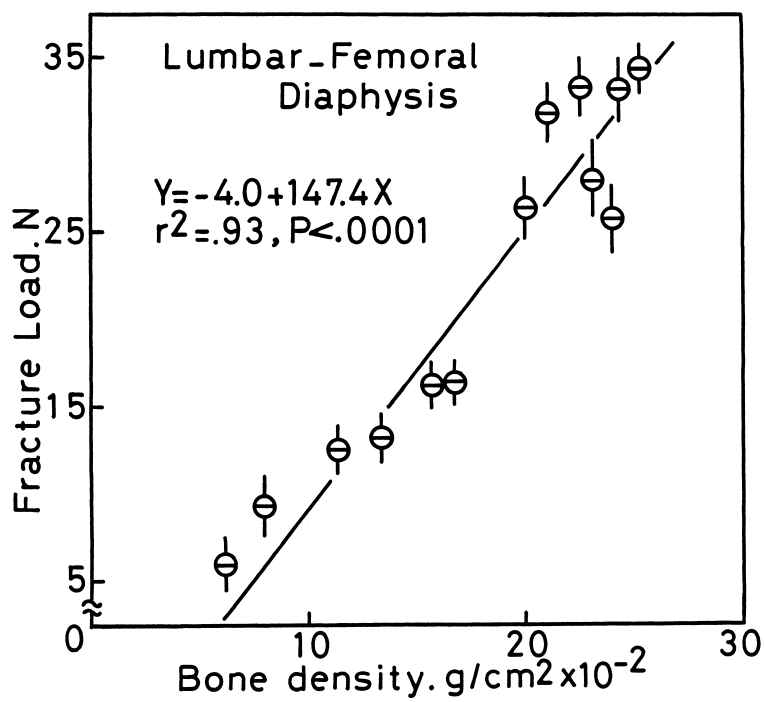

Fig.15 Relation between lumber fracture load and density of femoraldiaphysis.
大きくなり正の相関を有している .この関係の回帰式は図中 のような1次式になり有意差も確認された .

Fig.15は腰椎の破断荷重と大腿骨々幹部の骨密度の関係を 示す.ささきのチフネスと腰椎の骨密度と同樣に骨密度の増 加とともに破断荷重も大きくなって正の相関を有し有意差 も認められた .

骨密度は骨中に含有されている無機成分の総量を表して いる．骨 (海綿骨) の組成は無機質 $50 \%$ ，蛋白質 $30 \%$ ，水 15 $\%$, 多糖類 $5 \%$ から成り，無機質以外は骨の載荷能力に寄与 しない．したがって, 骨密度の高低によって骨の載荷能力が 決定される .

骨密度と力学特性の関係については, Vose と Kubalaが三点 曲げ試験による破断応力と X 線の吸収から求めた無機成分 の含有量との関係を調べ，無機成分の増加によって破断応力 が大きくなるという結果を得ている1).Cutreyは家兔の骨を用 い三点曲げ試験による破断応力および弾性率と，プラチナの ルツボに骨を入れ有機成分を燃焼させてしまう方法により 骨密度を求め同樣な結果を得ている2). 著者らも馬の第3中手 骨の三点曲げ試験をおこない破断応力，弾性率は骨密度は正 の相関を有し，有意差も依存することを明らかにした

\section{4. 結 論}

幼若期 (5週齢) から老年期 (98週齢) のラットの頸椎お よび腰椎の力学特性と骨密度を調べた結果, 以下の点を明ら かにした .

頸椎および腰椎の粘弾性特性を調べ, 硬さの目安となるス チフネスと粘弾性効果の指標である $\tan \delta の$ 週齢依存性を測定 し, 回帰式によりその関係を明らかにした . 頸椎と腰椎の週 齢による力学特性変化は, 頸椎は弾性的 (脆性) な材料に変 化しているのに対し, 腰椎は載荷能力, 粘弾性効果とも優れ た材料に変化し両者は相違した材料に変化していることが 判明した . 頸椎 , 腰椎ともに後方要素切除後ではスチフネス の值が40〜 60\%減少し，この減少分は後方要素が担っていた ことを明らかにした .

静的試験による頸椎および腰椎の破断荷重, 変形エネルギ の週齢依存性を調べ, 回帰式により関係を求めた . 頸椎の強 度の週齢依存性を明らかにした。

骨密度は大腿骨々幹部, 遠位部, 第3 腰椎を測定し, 週齢 依存性を明らかにした.第3腰椎は骨梁構造の变化を調へ，加 齢による骨梁の厚さと骨量の関係が明らかになった .

骨密度と力学特性はスチフネス, 破断荷重ともに正の相関 を有していることか確認された . (2000年9月26日, 第48回レ オロジー討論会 (高知市) にて発表)

\section{参考文献}

1) Vose GP, Kubala AL, Hum Biol, 31 (1985).

2) Curry JD, J Biomechanics, 2, 1 (1969).

3) 白崎芳夫, 立石哲也, 片桐 祐, 日本レオロジー学会 誌, 17 , 218 (1989). 